\title{
IMMUNOMODULATORY TREATMENT IN MULTIPLE SCLEROSIS
}

\section{Experience at a Brazilian center with 390 patients}

\author{
Charles Peter Tilbery', Maria Fernanda Mendes², Bianca Etelvina Santos de Oliveira ${ }^{3}$, \\ Rodrigo Barbosa Thomaz ${ }^{3}$, Giorge Ribeiro Kelian ${ }^{4}$
}

\begin{abstract}
Since 1993 the Federal Drug Administration approved the use of immunomodulatory therapy in multiple sclerosis (MS), modifying the natural course of disease, as demonstrate our experience in t reatment of MS patients at the MS Treatment Center (CATEM). Objective: To evaluate patient behavior using immunomodulatory therapy for a period of five years treatment. Method: We selected 390 patients in CATEM with relapsing-remitting MS (RRMS) and secondary progressive MS (SPMS) with relapses. Results: At initial treatment $292(61.5 \%)$ patients presented RRMS, 98 (20.6\%) SPMS with relapses, 27 SPMS (5.6\%) and $58(12.1 \%)$ primary progressive MS (PPMS). In RRMS $182(62.5 \%)$ used the interfe ron $\beta$ 1a SC, $15(5.2 \%)$ interferon $\beta$ 1a IM, 85 (29\%) interferon $\beta 1 \mathrm{~b}$ and 10 (3.3\%) glatiramer acetate. In SPMS 63 (64.3\%) used interferon $\beta$ 1a SC, 4 (4.1\%) interfe ron $\beta$ 1a IM and 31 (31.4\%) interf e ron $\beta 1 \mathrm{~b}$. We observed that in this period 195 (50\%) migrated between drugs, 35 (9\%) gave up therapy and 160 (41\%) continued the initial therapy. Conclusion: Stopping the immunomodulatory therapy emerges as a problem in the second year of treatment and it can be a subset of interf e ron non responsive or development of neutralizing antibodies.
\end{abstract}

KEY WORDS: multiple sclerosis, immunomodulatory therapy, treatment failure.

\section{Tratamento imunomodulador na esclerose múltipla: experiência em um centro brasileiro com 390 pacientes}

RESUMO - A partir de 1993, com a aprovação pela Federal Drug Administration (FDA) do uso de imunomoduladores na esclerose múltipla (EM), houve alterações significativas na história natural da doença. Objetivo: Avaliar o comportamento dos pacientes com uso de imunomoduladores no decorrer de 5 anos. Método: Foram atendidos 589 pacientes no CATEM, sendo selecionados 475 pacientes e excluídos os port a d o res das fo rmas pro g ressiva secundária sem surtos (PS) e pro g ressiva primária (PP). Resultados: No início do tratamento $292(61,5 \%)$ pacientes apresentavam a forma RR, 98 (20,6\%) forma PSS, 27 PS (5,6\%) e $58(12,1 \%)$ PP. Na forma EMRR $182(62,5 \%)$ utilizaram o interf e ron $\beta$ 1a SC 3x/semana, 15 (5,2\%) interfe ron $\beta$ 1a IM 1x/semana, $85(29 \%)$ interf e ron $\beta 1$ b e $10(3,3 \%)$ acetato de glatiramer; na forma EMSP $63(64,3 \%)$ utilizaram o interferon $\beta$ 1a SC, 4 (4,1\%) interferon $\beta$ 1a IM e $31(31,4 \%)$ interferon $\beta$ 1b. $35(9 \%)$ pacientes pararam de utilizar a medicação, 195 (50\%) migraram entre imunomoduladores e $160(41 \%)$ pacientes continuaram usando o imunomodulador inicial. Conclusão: Não tivemos a intenção de comparar os interferons $\beta$ a fim de demonstrar qual o melhor ou qual teve maior falência. Contudo, é fato que o risco de falência das medicações a partir do segundo ano de tratamento ocorre e pode ser por pacientes não responsivos aos interferons $\beta$ ou ao surgimento dos anticorpos neutralizantes.

PALAVRAS-CHAVE: esclerose múltipla, terapia imunomoduladora, falha terapêutica.

Since 1993, the Federal Drug Administration (FDA) a p p roved the use of immunomodulatory therapy in multiple sclerosis (MS), modifying the natural course of disease ${ }^{1}$. In 1997, and after in 2001, The Health
Department approved this medicine for the use in our enviroment ${ }^{2}$, modifying as from those dates the course of MS in Brazil. In the city of São Paulo the prevalence of MS is $15 / 100000$ inhabitants $^{3}$. In April

Central of Attendance of Multiple Sclerosis Treatment (CATEM), Discipline of Neurology of the Santa Casa of São Paulo, Brazil (FCMSCSP): ${ }^{1}$ Assistant Professor and Neurology Head Principal of Discipline of FCMSCSP; ${ }^{2}$ Neurologist Doctor, Assistant Professor of FCMSCSP; ${ }^{3}$ Neurologist Doctor of the CATEM; ${ }^{4}$ Neurologist Doctor post graduated in neurology at the FCMSCSP.

Received 9 May 2005, received in final form 31 October 2005. Accepted 1 November 2005. 
of 1997 the Assistant Center and Treatment of MS (CATEM) of the Neurology Discipline of the University of Medical Science Santa Casa of São Paulo was created. Since then, patients with MS have been evaluated and included in the protocol treatment with immunomodulators ${ }^{1}$. MS is an inflammatory demyelinating disease of the Central Nervous System (CNS) more frequent in North America and North of Europe $^{4}$. The disease is the result of aggression of the myelin shaft in the CNS, causing oligo and axonal lesion. Provoking young adult's age between 20 and 40 years old, causing incapacity in more than $50 \%$ of the patients ${ }^{5}$. The etiology of the disease is still unknown and the symptoms vary depending on the lesion localization, the most commom are: sensitive symptom, sphincter dysfunction, optical neuritis, ataxia, diplopia and the pyramidal motor deficit 5 . MS can develop in several ways: recurring-remittent way (RRMS), pro g ressive secondary way (SPMS) with and without outbreaks and primary pro g ressive (PPMS) ${ }^{6}$.

Interferon $\beta$ was the first drug to demonstrate immunomodulatoryquality, followed by glatiramer acetate, as it controls more specifically the dere $\mathrm{gu}$ lation of the present immune system in $\mathrm{MS}^{7-9}$ and the studies demonstrate yet direct effects related to outbreaks and the appearance of incapacities ${ }^{4,10,11}$.

The objective of this study is to evaluate patient's behavior with the use of immunomodulators durind 5 years. The efficiency os the established drugs has not been analyzed.

\section{METHOD}

589 patients were attended at CATEM and 475 patients were selected with defined diagnosis of MS according to criteria of Poser et al. ${ }^{12}$, between May of 1997 and June
2003 (1 year/5 years). Patients are attended at CATEM with inconclusive diagnosis from several places of São Paulo and Brasil that are attended through appointments for the diagnosis confirmation, behavior and future follow-up. This $g$ roup (475) included patients of both genders, with age between 18 and 50 years old and classified by the Lubling et al. ${ }^{6}$ criteria in RRMS way, secondary progressive with outb reaks (SPSMS), SPMS without outbreaks and PPMS, being 292 RRMS, 98 cases SPSMS, 27 SPMS and 58 PPMS.

The patients were oriented to use immunomodulators according to standards and guidelines of the Health Department in accordance with the clinical forms, degree of functional incapacity, presence of other associated diseases ${ }^{1,2}$.

We submitted the patients to neurological evaluation everysix months. Degree of functional incapacity, presence of adverse side effects, suspension of drugs, disease progression or treatment abandon were noted, 85 (14.4\%) patients were excluded. They were bearers of SPMS and PPMS type without outbreaks (as they did not use immunomodulators), 114 patients (19.3\%) that did not $\mathrm{p}$ resent MS or those that had incomplete re co rds or that abandoned the treatment before a period of one year.

\section{RESULTS}

Results are summarized in Tables 1 to 5 .

During initial treatment 292 patients $(61.5 \%)$ presented RRMS type, 98 (20.6\%) SPSMS, 27 SPMS (5.6\%) and $58(12.1 \%)$ PPMS. Average age at the diagnosis was 31.3 in RRMS type, 37.5 SPMS and 43.3 in PPMS type years old. Type RRMS revealed $25 \%$ male sex and $75 \%$ female. SPMS $27 \%$ male and $73 \%$ female and in PPMS type $86 \%$ female and $14 \%$ male.

The majority of the 390 patients $(82.1 \%)$ started treatment with immunomolators and the main adverse effects were skin allergy reaction, shivers, fever, myalgias, being transitory and that occurred

Table 1. Patients that started the use of immunomodulator.

\begin{tabular}{lccccc}
\hline Clinical form & $\begin{array}{c}\text { Interferon } \beta \text { 1a SC } \\
(n=245 / \%)\end{array}$ & $\begin{array}{c}\text { Interferon } \beta \text { 1a IM } \\
(n=19 / \%)\end{array}$ & $\begin{array}{c}\text { Interferon } \beta \text { 1b } \\
(n=116 / \%)\end{array}$ & $\begin{array}{c}\text { Glatiramer acetate } \\
(n=10 / \%)\end{array}$ & $\begin{array}{c}\text { Total } \\
(n=390)\end{array}$ \\
\hline EMRR & $182 / 46 \%$ & $15 / 3.8 \%$ & $85 / 21.8 \%$ & $10 / 2.5 \%$ & 292 \\
EMSP & $63 / 16.1 \%$ & $04 / 1 \%$ & $31 / 8 \%$ & 0 & 98 \\
\hline
\end{tabular}

EMRR, multiple sclerosis recurring-remittent; EMSP, multiple sclerosis secondary progressive.

Table 2. Patients that stopped using of immunomodulators.

\begin{tabular}{lcccc}
\hline Clinical form & $\begin{array}{c}\text { Interferon } \beta \text { 1a SC } \\
(\mathrm{n}=25 / \%)\end{array}$ & $\begin{array}{c}\text { Interferon } \beta \text { 1a IM } \\
(\mathrm{n}=2 / \%)\end{array}$ & $\begin{array}{c}\text { Interferon } \beta \text { 1b } \\
(\mathrm{n}=8 / \%)\end{array}$ & $\begin{array}{c}\text { Total } \\
(\mathrm{n}=35)\end{array}$ \\
\hline EMRR & $08 / 2 \%$ & $02 / 0.5 \%$ & $02 / 0.5 \%$ & 12 \\
EMSP & $17 / 4.3 \%$ & 0 & $06 / 1.5 \%$ & 23 \\
\hline
\end{tabular}

EMRR, multiple sclerosis recurring-remittent; EMSP, multiple sclerosis secondary progressive. 
Table 3. Patients that migrated between the immunomodulators.

\begin{tabular}{lccccc}
\hline Clinical form & $\begin{array}{c}\text { Interferon } \beta \text { 1a SC } \\
(n=121 / \%)\end{array}$ & $\begin{array}{c}\text { Interferon } \beta \text { 1a IM } \\
(n=6 / \%)\end{array}$ & $\begin{array}{c}\text { Interferon } \beta \text { 1b } \\
(n=63 / \%)\end{array}$ & $\begin{array}{c}\text { Glatiramer acetate } \\
(n=5 / \%)\end{array}$ & $\begin{array}{c}\text { Total } \\
(n=195)\end{array}$ \\
\hline EMRR & $79 / 20.2 \%$ & $06 / 1.5 \%$ & $30 / 7.7 \%$ & $05 / 1.3 \%$ & 120 \\
EMSP & $42 / 10.7 \%$ & 0 & $33 / 8.4 \%$ & 0 & 75 \\
\hline
\end{tabular}

EMRR, multiple sclerosis recurring-remittent; EMSP, multiple sclerosis secondary progressive.

Table 4. Demographic characteristics of patients that used the immunomodulators at the treatment start.

\begin{tabular}{lcc}
\hline & $\begin{array}{c}\text { EMRR } \\
(n=163)\end{array}$ & $\begin{array}{c}\text { EMSP } \\
(n=40)\end{array}$ \\
\hline Average - age & 31.4 & 33.1 \\
Male sex (\%) & 20.7 & 5.4 \\
$\begin{array}{l}\text { Female sex (\%) } \\
\begin{array}{l}\text { Time usage of the } \\
\text { immunomodulators before } \\
\text { discontinuing or migrating } \\
\text { average (years) }\end{array}\end{array}$ & 59.6 & 14.3 \\
\hline $\begin{array}{l}\text { EMRR, multiple sclerosis recuring-remittent; EMSP, multiple sclerosis } \\
\text { secondary progressive. }\end{array}$ & 2.6 & 2.0 \\
& &
\end{tabular}

Table 5. Reason survey for migration between the immunomod ulators.

\begin{tabular}{lc}
\hline Reason for migration & $\mathrm{n}=120$ \\
\hline Therapeutic error & $4.6 \%$ \\
Progression & $11.5 \%$ \\
Adverse reactions & $15 \%$ \\
Pregnancy & $13.8 \%$ \\
Abandon & $18.4 \%$ \\
Not specified & $36.7 \%$ \\
\hline
\end{tabular}

in 72 cases $(18.6 \%)$. We observed that during this period 92 patients $(23.6 \%)$ converted from type RRMS to SPMS, 195 (50\%) migrated between immunological modulators and $108(27.7 \%)$ used other associated drugs (immune supressive, immune globulins, symptomatic medicine).

In 157 patients (54\%) of type RRMS, we achieve in verifying, the type of first outbreak of the patient, this being $25.5 \%$ sensitive and the optical neuritis with $22 \%$. Initially in type RRMS $182(62.5 \%)$ used interferon $\beta$ 1a SC 3x/week, 15 (5.2\%) interfe ron $\beta$ $1 \mathrm{a}$ IM once a week, $85(29 \%)$ interferon $\beta 1 \mathrm{~b}$ and 10 (3.3\%) glatiramer acetate; type SPMS $63(64.3 \%)$ used interferon $\beta$ 1a SC, 4 (4.1\%) interferon $\beta$ 1a IM and
31 (31.4\%) interferon $\beta$ 1b. 35, (9\%) patients stopped using medication, $19(16.1 \%)$ migrated due to therapeutic progression failure of the illness and $18(15 \%)$ due to adverse reactions, $305(78.2 \%)$ patients completed 1 year of treatment and $66(17 \%)$ completed 5 years treatment.

\section{DISCUSSION}

The criteria adopted by McDonald et al. were published in 2001, after the therapy start and so asto maintain the uniformity we used the Poser et al. ${ }^{12,13}$. The patients average that stopped using interferon in EMRR is 6 patients/per year, at EMSP it is 2.6 patients/per year and these values are less than those reported by the major multicenters. At the start accompaniment of these patients there was no glatiramer acetate available in Brazil (1997 to 2000); therefore some patients had to suspend interferon use because they had no alternative to use another medication ${ }^{2}$, with the exception of judicial law access.

In Table 1 we presented 10 patients that started their treatment with glatiramer acetate, of these 5 patients migrated to another drug. As from 2001 free dispensation of glatiramer acetate started ${ }^{2}$, after this we managed to start a survey related to this migration, 32 patients changed interf e rons to glatiramer acetate.

The average age was 35.2 years, $81.2 \%$ of the female sex and $18.8 \%$ male sex, $37.6 \%$ used interferon $\beta 1 \mathrm{~b} \mathrm{SC}, 3.1 \%$ interferon $\beta 1 \mathrm{a}$ IM and $59.3 \%$ interferon $\beta 1$ a SC before they migrated to glatiramer acetate, 53\% were EMRR and 47\% EMSP. Related migration reason: $37.5 \%$ was due to a progression and $37.5 \%$ for therapeutic error, $12.5 \%$ for adverse reactions, 6.25 due pregnancy and in $6.25 \%$ the reason for the change was not specified.

The time elapsed to change medication was in average 3.5 years and the disease development time of these patients was average 3 years. We still have a short time period of glatiramer acetate use, so as to explain about the same. In relation to interferons $\beta$ we did not have intention of comparing than so as 
to demonstrate which the best was and the worst, but several studies and surveys demonstrate that in efficiency terms of medications all maintain the same average $\mathrm{e}^{5,8,11}$. However, it is a fact that the drug risk failures occurs in the second year treatment, and could be due to the lack of patients response to the interferons $\beta$ or to the emerging neutralizing antibodies $^{8}$.

The problem consists of one item as the majority of patients that use interfe ron $\beta$ are not submitted to periodical antibodies mensuration (including this actual study/survey $)^{8}$. Another question is the diff $i-$ culty to know what is and how to determine therapeutic failure, even though being something subjective in science area ${ }^{8}$. We found certain difficulty to gather some retrospective information of these patients, attributable to medical team failure related to filling out of patients records.

\section{REFERENCES}

1. Tilbery CP, Moreira MA, Mendes MF, Lana-Peixoto MA and The Brazilian Committee for Treatment and Research in Multiple Sclerosis, BCTRIMS. Recomendações para o uso de drogas imunomoduladoras na Esclerose Múltipla. Arq Neuropsiquiatr 2000;58:769-776.
2. Secretaria de Assistência à Saúde, Ministério da Saúde. Portarias no 97 e 98. Diário Oficial da União 23 de março de 2001.

3. Callegaro D, Goldbaum M, Morais L, et al. The prevalence of multiple scle rosis in the city of São Paulo, Brasil. Acta Neurol Scand 2001;104: 208-213.

4. Filippini G, Munari L, Incorvaia B, et al. Interferons in relapsing remitting multiple sclerosis: a systematic review. Lancet 2003;361:545-552.

5. Carra A, Onaha P, Sinay V, et al. A re t rospective, observational study comparing the four available immunomodulatory treatments for relapsing-remitting multiple sclerosis. Eur J Neurol 2003;10:671-676.

6. Lubling FD, Reingold SC. Defining the clinical course of multiple sclerosis: results of a international survey. Neurology 1996;46:907-911.

7. Dhib-Jalbut S. Mechanism of action of interferons and glatiramer acetate in multiple sclerosis. Neurology 2002;58(Suppl 4):S3-S9.

8. Rourke A, Hutchinson M. Stopping beta-interferon therapy in multiple sclerosis: an analysis of stopping patterns. Multiple Sclerosis 2005;11: 46-50.

9. Tremlett H, Oger J. Interrupted therapy: stopping and switching of the $\beta$-interferons prescribed for MS. Neurology 2003;61:551-554.

10. Freedman MS, Blumhardt LD, Brochet B, et al. International consensus statement on the use of disease-modifying agents in multiple sclerosis. Multiple Sclerosis 2002;8:19-23.

11. Prieto JM, Lenna M. Interferon $\beta$ en la esclerosis múltiple. Neurology. 2003;36:980-990.

12. Poser CM, Paty DW, Scheinberg LC, et al. New diagnostic criteria for multiple sclerosis: guidelines for research protocols. Ann Neurol 1983;13: 227-231.

13. McDonald WI, Compston A, Edan G, et al. Recommended diagnostic criteria for multiple sclerosis: guidelines from the international panel on the diagnostic of multiple sclerosis. Ann Neurol 2001;50:121-127. 